\title{
Russian New Industrialisation Policy as a Change-Over Method to the Postindustrial Economics
}

\author{
Irina Yurievna Vaslavskaya \\ Yulia Yevgenyevna Yangirova
}

Doi:10.5901/mjss.2015.v6n3p174

Kazan Federal (Volga Region) University Branch in Naberezhnye Chelny, 423812, Tatarstan,

Naberezhnye Chelny, 68/19 (1/18)

\section{Abstract}

Hydrocarbon export-focus, step-by-step degradation and critical situation in the industrial branch, native goods displacement by the import, high energy dependence and attachment to the world raw prices make the Russian Economics ineffective, noncompetitive and unstable to crisis. The key point of this research is to show the aspects that are necessary for creation country postindustrial development. Developed and developing GDP structure and growth analysis has led to the definite conclusions as for the necessity of competitive industrial sector with high percentage of innovative product creation. In the article also presented the consequences of the highly developed countries' actions relative to the productions transfer in the countries with the lowest economic costs. There is shown that Russia's postindustrial economic development change-over is impossible without creation of the effective competitive industrial sector based on state-private partnership.

Keywords: new industrialization, postindustrial economics, innovative activity, industrial sector, state-private partnership.

\section{Introduction}

More than twenty years ago Russia changed socialistic development way on liberal, chose market economy instead of command-planned economy. In the 1990s Russian Federation after realizing economic reforms faced with several socialeconomic problems such as hyperinflation, economics barter, decreasing country GDP, brain drain, cutoff scores industrial productions, criminality increasing, decreasing real population's salary [Kara-Murza, 2008]. For instance, GDP increasing tempo decreased by 15 percentage. In the post socialistic countries recovering period took in average 3-4 years. Russia at the same time was able to rehabilitate the pre-crisis level of GDP of the 1989 year, only by 2007 thanks to costs conditions on the world raw and energy market of the 1999-2000s [RFSSS, 2014).

Liberalization of the foreign commerce and costs, and also new taxation policy have led the production to the critical point in all industrial spheres: construction engineering, mechanical engineering, shipbuilding, consumer goods, foodstuff and manufacturing industries reduced the country size production of more than two, moreover lots of factories lost almost all the circulating assets because of hyperinflation.

As a consequence of the hyperinflation the population salaries, savings and incomes depreciated, salary payments became irregular, barter took place in the economics [Esipov, 2007].

These consequences of the created so-called quasimarket economy, characterized as imperfect and incomplete, with obvious presence of the populism and lobbying of the modern class property owners after privatization, nowadays have strong influence [Lopatnikov, 2006].

Critical situation in the industrial sector generate a chain of interconnected social-economic problems. Statistic data and comparative characteristic of the industrial cluster of the 2010 and 1990s are declarative of a serious disruption in the basic spheres of the Russian industry after USSR disintegration. In order to determine post-soviet period market economy results we go over several facts. Definitely, in order to take into account common territorial factor and only industrial sector, we should compare only Russia and RSFSR.

Industrial production coefficient decreased more than by 50 percentage in comparison with the level of 1991 . Since 2000 s this index in Russian Federation is increasing, but is not able to reach pre-reform period rates.

Steel production in the RSFSR in 1971 amounted 66,8 million ton, in the crisis 1991 were produced 77,1 million ton, and in 2012 there were 70,4 million ton. It means that production rates in this period still have not reached twenty years ago rates, that automatically pushes the country twenty years back as for the steel production [RFSSS, 2014]. The similar situation is in the steel tubs production.

The key coefficient for industrial developed country is the machine and equipment production index. Last twenty years in the mechanical engineering takes place gradual native goods displacement by the import.

Machine and equipment production index in Russia decreased more than 70\% in 1998 in comparison with 1991. In 
2007 machine production was seriously strengthened, but still the best rates are 30\% lower than in 1991. Black metals roll stock was in 2012 61,8 million tons, in 2010 - 57,8 million tons, in 1990 - 63,7 million tons, in 1978 - 60,1 million tons [RFSSS, 2014].

Agrocultural machines production decreased in modern Russia 28 times and variety of products were totally displaced by the import. This type production degradation, exactly agricultural tractors, was gradual: $1991-178$ thousand ones, $1994-27$ thousand ones, 1999 - 15,4 thousand ones, in 2010 - 6,2 thousand ones, in 2012 - 17,8 thousand ones [RFSSS, 2014]. It seems impossible to catch up with last years rates, despite active agriculture subsidizing by the government.

Construction-highway machines production also has strong cutoff. The following data about excavator production is observed: $1984-27,1$ thousand ones, 1991 - 21,1 thousand ones, $2010-2,1$ thousand ones, $2012-1,9$ thousand ones. Stable regress took place in production and practically total machines displacement by the import ones.

Vehicles production is characterized by decreasing rates: 1970 - 445 thousand ones, 1991 - 616 thousand ones, 2010 - 153 thousand ones [RFSSS, 2014].

So, there can be obviously observed gradual degradation in the industrial sector in Russian Federation. The main problems that the country faced with are the loss of working capacity in the end market and the replacement by the import. [Kara-Murza, 2008] Russia has not managed to achieve twenty-years-old rates in the production sector, it has not succeed in renewal of the industrial cluster and in looking on new markets. Russian Economy oriented on the hydrocarbon export last twenty years turned to the pre-industrial age. High country energy and also economy world costs dependence, native goods displacement by the import and high level of commerce in sectorial structure - it's far not complete list of standard points turned out in the economic state of Russian Federation. This way of development will not let the country be the leader in some economic statistics.

The industrial sector for developed countries is the basis for stable, effective economy; consequently, its absence may turn out unbearable obstacle in crisis periods [Dabrowski, 2009]. The 2008-2009s world economic crisis is the proving for this. It demonstrated that the countries with small industrial sector had bigger GDP decrease than in any industrial country. Poland is the country oriented on the export in the developed EU countries, that is why its GDP continued increasing, but at the same time Russian GDP lost 9\%. High participation in industrial sector, based on competitiveness and innovative development that is what definitely guarantee stable and qualitative growth of the most important economic rates is the Russian Federation economic structure. It will create more stable and less world costs dependent economy [Tatarkin, 2014].

\section{Method}

Nowadays there exist several approaches to postindustrial economic development of different countries. One of the intendings: "Developed countries do without industrial cluster". Actually, given excess takes place to be, that is rare to be come across though, in comparison with blanket situation. For example, participation of the manufacturing industry in postindustrial England amounts 20,8\%, in Germany - 30,5\%, in USA - 19,2\%. China, India, Brazil are the most promptly developing countries, thanks industrial sector they provide GDP increase.

Table 1 - Developed and developing countries GDP structure

\begin{tabular}{|c|c|c|c|}
\hline \multirow{2}{*}{ Country } & \multicolumn{3}{|c|}{ GDP sectors } \\
\cline { 2 - 4 } & Agriculture & Industry & Human-services \\
\hline \multicolumn{4}{|c|}{ Developed countries } \\
\hline USA & 1,1 & 19,2 & 79,7 \\
\hline Germany & 0,8 & 30,5 & 68,6 \\
\hline Great Britain & 0,7 & 20,8 & 78,5 \\
\hline Japan & 1,1 & 26,1 & 72,8 \\
\hline Canada & 1,7 & 28,5 & 69,8 \\
\hline \multicolumn{5}{|c|}{ Biggest promptly developing countries } \\
\hline China & 10,1 & 45,3 & 44,6 \\
\hline India & 17,4 & 17,6 & 65,0 \\
\hline Pakistan & 24,4 & 22,0 & 53,6 \\
\hline Brazil & 5,2 & 26,8 & 68,5 \\
\hline Russia & 4,2 & 37,5 & 58,4 \\
\hline
\end{tabular}

Source: World Fact Book [Electronic resource]. URL: https://www.cia.gov/library/pubications/the-world-factbook/geos/pk. html [date of referring: 14.03.2014] 
So, the leader in the industrial sector is China, its participation in industry amounts $45,3 \%$ of all GDP. It is not just coincident that this country is known as "world workshop." In the sphere of human-services USA $(79,75 \%)$, Great Britain $(78,5 \%)$ and Japan $(72,8 \%)$ are the leaders, and thanks exactly to these countries World Economy turned out to be financially inflated and virtual, unable to react to the world economic crisis. World crisis appeared very strong in the USA and Europe, also showing state debt increase. For example in 2007-2012 period, state debt in Germany increased from $65 \%$ to $82 \%$ of GDP volume, USA debt increased from $66 \%$ to $107 \%$.

Table 2 - GDP increase in developed and developing countries in 2001-2012, number of multiplies

\begin{tabular}{|c|c|c|c|}
\hline \multicolumn{2}{|c|}{ Developed countries } & Developing countries \\
\hline USA & 1,2 & India & 2,9 \\
\hline Germany & 1,1 & Pakistan & 2,2 \\
\hline Great Britain & 1,2 & Brazil & 1,7 \\
\hline Japan & 1,1 & Russia & 1,5 \\
\hline Canada & 1,2 & 1.6 \\
\hline
\end{tabular}

Source: World Fact Book [Electronic resource]. URL: https://www.cia.gov/library/pubications/the-world-factbook/geos/pk. html [date of referring: 10.04.2014]

Last time in there is a tendency in the World Economy of decreasing of developed countries growth dynamics and increasing of developing ones, that definitely leads to change the world periphery correlation and world developing center, moreover lodgment of some countries with uncharacteristic for them economic power and geopolitical influence.

\section{Results}

Lop-sided vision of the Russian Economy in postindustrial spheres development is not able become a break of economic growth of Russian Federation. Postindustrial economy is unable to develop separately from industrial sector, as a primary consumer of innovative product. Postindustrial development of Russian Federation economy should be based on the priority of innovative sector with high-productive industry and realizing structural and institutional reforms, directed on economy flexibility increase.

Differential factors of postindustrial economy from industrial one are human capital, high level of life quality, venture business, developed innovative sector with hi-tech production. The main idea of postindustrial economy comes to increase of human-services and consequently decrease of industrial cluster participation in GDP at the expense of innovative hi-tech productions development. However, low participation or its decrease in not the index of postindustrial economy. For example, in Russian Federation human-services participation in 2010 amounted 62,7\%, industry participation - 27,5\% of GDP. In Ukraine Economy human-services participation amounted 56\%, industry participation $23,2 \%$. However, significant human-services predominance does not mean that above-listed countries economy is postindustrial. Russian economy is characterized as raw, with noncompetitive industrial sector and high level of native goods replacement by the import. That is far not characteristic of postindustrial economy. Absolutely contrary situation is in Belorussia, human-services participation in its GDP amounts $44,4 \%$, industrial participation - $46,2 \%$. But economy is industrial with low participation of raw economy.

In 2012 the United States of America formerly exported productions in countries with cheap forces of production and minimal economic expenses thanks to invisible hand of market economy, started to return the industrial sector back into the country. American production transferring process in countries with the less economical expenses has led to increase of unemployment, decrease of a real salary in the given country [Vedomosti, 2013]. In 2010 in Detroit was organized the meeting of the White House officials, states governors and Congressmen with the heads of automobile corporations for the purpose of returning work-places and productions transferring back into the United States of America. The USA government actively support the companies working on the US territory, rendering benefits and subsidy for employees retraining [Stiglitz, 2011]. According to the BCG rating productions returning and export increase will let by the end of decade create in the USA industrial sector 0,6-1,2 million work-places, and taking into account multiplicative effect and employment growth human-services with productions enlarging - 2,5-5 million workplaces. Insourcing process goes rapidly not only in the USA, but also in Canada and Great Britain [KM, 2012]. According to the prognosis since 2014-2018 an average World Economy growth tempo will accelerate and will be on the level of $4 \%$ [GEP, 2014]. It will be thanks to returning of the industrialization policy in the developed countries [Rodnik, 2010]. 
Innovative activity cannot be created in an empty place, some technological basis in the industrial sector is necessary for the creation of new appreciation as an innovative product, having a potential interest of the consumer. At the same time even the novelty created in laboratories of innovative parks cannot to become relevant, because in Russia practically absent the technological basis, which could apply and use given elaborations and also to produce on their basis competitive hi-tech production. Because of these reasons created in recent time technologies became the innovation source of other countries or devaluated, not finding application and losing their actuality The participation of the shipped innovative production amounts only $5,5 \%$, however, for the reasons of economic safety this index should be on the level of 15\% and more. In order to achieve this level by 2019 it is necessary to increase the participation of innovative product $2 \%$ per year [Nekipelov, 2013]. It is necessary to create working programs, but not national projects which are called upon depicting their decisions [Biryukov, 2011].

\section{Discussion}

As the result of everything said, we consider that it is necessary to improve partner relations system between state and business. State-private partnership proved its budget and social-economic effectiveness in the world practice. Effective realization of new innovative industrial policy is impossible without partnership of state and private sector. The government should determine development priorities, create profitable legal framework and stimulate involvement for the realization investment projects financial resources, hi-tech technologies, innovative decisions and employee potential of the private partner.

On Moscow economic forum, which took place in MSU in March 2014, the thesis:"Russian industrial policy: privatestate or state-private partnership?" had been actively discussed by Russian economists, theoreticians and experts, and also by the representatives of the world community [MEF, 2014]. This topic actuality is connected with the increase of government participation in financial mobilization and first of all investment resources. In 2009 on the first Russian economic congress by the author of the article was done the report, in which state-private partnership (SPP) was examined as the modern universal mechanism of economic development, which gives an opportunity through the cooperation of state and business, focused on all society development, to achieve economic effect. However, stateprivate partnership realization is complicated by several problems legal, economic and administrative character [Vaslavskaya I., 2014].

State-private partnership is defined as the system of economical, organizational, lawful and social relationships arising between the government and the private sector of the national economic.

State-private partnership organization allows to cope with difficult social-economic problems by involvement of government and private sector resources. As the result of such partnership relations state innovative and investment programs are put into effect more effective and resulting [Tatarkin, 2009]. State-private partnership acquires a particular significance while realizing of large-scale innovative projects. Let us view exactly the state-private partnership while realizing of large-scale innovative projects in the national economy system.

State-private partnership organization by the state and private sectors interaction concerned with the necessity of working up of useful for this particular case law base, tax stimulation extents accordance, organizational preferences usage, normative and law base introduction, institutional structure reforming by negotiated relationships creating, and also the ownership definition on the activity results.

Theoretical basis of the state-private organization concerned with economically reasonable business offers formulating, which reflects tendencies of developing and increasing of a country economic competitiveness from the point of view of the business and financing effectiveness increasing, management and economical activity increasing in the national economy from the position of the state.

State-private partnership should be based on parity relationships among innovative projects participants [Makarov, 2010]. De facto state-private partnership supposes important social services specter definition from the position of the state power, but from the position of private entrepreneurs - all possible variants of formulated problem solution definition. However, it does not say anything about the primary and essential initiative from the state position, but only defines the direction of vector in the social-economic development directions.

It's necessary to note that the state-private partnership while realizing projects bases on voluntary partnership from both sides, state structures and business for cooperative work on the achieving of the formulated point.

Examining advantages and disadvantages of state-private partnership usage as the large-scale innovative projects mean, it is necessary to define:

- significant financial resources attraction from the side of commercial sector participants, and also timely and sufficient large-scale innovative projects; 
- $\quad$ financial costs decrease from the side of state on the support of effective managing and objects;

- $\quad$ effective risks distribution between private and state large-scale innovative projects participants;

- infrastructure improvement and approach application to infrastructure objects managing;

- increasing of investment attractiveness of various national economy sectors;

- transferring of objects managing to the definite private individuals for financial effectiveness increasing.

It is also possible to examine advantages of state-private partnership organization as large-scale innovative projects realization mean separately for the each participant of the given project. There are plenty of advantages for business, methodical and resource state support exactly, investments rendering for large-scale innovative projects realization with definite financial guarantees, decrease of the project risks level, project-financing rendering. There are also advantages for state while using state-private partnership as the large-scale innovative projects realization mean: increasing of budget matriculation volumes, qualitative work and service rendering from the private sector, increase of the innovative and investment activity level in the national economy branches, support of a high level economical activity and competition in the national economy branches, high level of structures managing effectiveness of large-scale innovative projects [Kireyeva, 2012].

However, there are also disadvantages as for the state-private partnership as large-scale innovative projects realization means:

- possibility of asymmetrical information streams forming because of the state employees competitiveness lack in the arriving investment opportunities examination;

- not always fair intentions of the private sector participants, willing to use various administrative and financial resources, provided by the state sector without any;

- transferring of arriving risks of large-scale innovative projects to the state and consequently on.

Let us examine disadvantages of using of state-private partnership for the state and the private sector separately as the given projects participants.

While using state-private partnership as large-scale innovative projects realization mean there arrive the following disadvantages for the private sector: significant political and juridical risks rise, concerned with change of strategic goals and priorities of the state policy, increasing private sector dependence from state tactical objectives, lesser loyalty and increasing terms of large-scale innovative project realization by means of coordination necessity with the state sector, significant technical risks rise, concerned with building and effective infrastructure objects using, especially in the case of indefinite formed environment conditions for large-scale innovative projects realization, limited private sector activity freedom because of joint solutions with the state sector [Grebennikov A.V., 2010].

For the state using of state-private partnership leads to the following disadvantages: democratically participation and state controlling absence of large-scale innovative projects results, financial burden increasing on citizens as for the working up and realization of innovative projects, following privatization of intellectual labor results by the private sector.

Large-scale innovative projects grow up, as a common, from small ideas which appear as small innovative business. Let us examine small innovative business as one of the forms of innovative national economy activity existence.

Small innovative business is an independent organization that deals with working up and commercialization of intellectual labor results of the budget organizations, predominantly higher education institutes. The main reason of small innovative business appearance has become the necessity in commercialization of scientific elaborations of the higher education institutes, that before the application in August, 2009 of the federal law 17. \#217-FL «About the entry of changes in separate law acts of the Russian Federation as for the questions of creation by budget scientific and educational institutes economic associations for practical using (entry) of intellectual activity results, contradicted with the principle of prohibition on the commercial activity for higher education institutes. Consequently, a small innovative organization by the higher education institutes appealed to commercial activity.

Innovative country development strategy should be created by the state and worked up for all participants of the given process. Firstly, for small innovative business development by the higher education institutes as the subject of intellectual resources concentration. Large-scale organizations, if they generate innovative elaborations, most probably, they will be probated and of the foreign high quality production, such activity can difficultly be called innovative. It is also necessary to pay significant attention in the innovative activity to cooperation of offer and demand of innovative technologies. State eagerly develop offer on the innovation, but pays very little attention to demand forming. There exists discrepancy of clause and demand on the modern innovation market. Innovative offers are in the non-demanded areas, but demand on innovation in areas which are weakly developed on the country, exactly laser and informativecommunicative. The demand on innovative activity results has not been discovered yet, potential consumers have not been revealed, it is quite difficult to define prospective directions of the small business development, to define innovative 
potential. It is necessary to stimulate the demand on innovative technologies, elaborations by the state, it is possible by means of strict requirements to the ecology, energy effectiveness [Vertakova, 2013]. The given methods are able to stimulate only insignificant rise of activity in innovative work, that is not capable to cause long-term, stable economic rise. Also the history of the Russian Federation has led to creation of large number of companies of monopolistic character, which do not put high competitiveness on the head position, and consequently do not stimulate innovative elaborations. Requirement in innovations can appear only in condition of absolute competitiveness in each economic sector. In the last decade Russian market becomes more competitive, cutting activity of monopolies, creating condition for good competitiveness, that became the main reason for creation of innovative-technological potential, transferring to innovative economy with activation, as the main subjects, small innovative organizations.

Small organizations analysis in innovative sphere shows the following peculiarities: narrow specialized direction of the scientific elaborations; producing of the small parcel production. Small organizations activity analysis discovered the following specialization: more than a half of small innovative organizations are busy with projecting of new techniques, the second place takes working up of program support, and the third - elaboration of nanotechnologies and new materials. Small firms, for example, create many innovations: microprocessor, personal computer, various program support. It is definitely possible to say, that small innovative organizations takes a significant place in the development of scientifictechnological progress.

\section{Conclusion}

Industrial policy is the conception which was rejected during long years by liberal economists, but obtaining bigger importance and ponderability in modern world. So, the key moment in the change-over process from industrial to postindustrial Russian development way is not decrease of industrial production and services participation increase, but creation of competitive production on the basis of state-private partnership, with the help of which industrial volumes increase slower thanks to absolute demand satisfaction than volumes of increasing services demand. Consequently, Russian Federation should enlarge the participation of industry in GDP, create competitive industrial sector, what in the future will lead to postindustrial economy with the help of innovative activity development. According to our point of view, the country cannot examine the opportunity of change-over to the postindustrial development with stable economy without creating effective industrial sector.

As the result, there exist critical necessity in development of sector of small innovative business, which will have significant social-economic effect in the national economy, and also strictly built system of state-private partnership as large-scale innovative projects realization. The main forming factors of innovative economy will be: rise of the scientific works and fundamental theoretical knowledge role; enlarging the sector of service; widening of the education role; predominance of the hi-tech goods, created in small innovative organizations. Cooperation of the main institutes of innovative activity is the main cause for creation and functioning of the innovative system of the country economy.

\section{Acknowledgement}

The authors acknowledge receiving support from state-funded research program of Kazan Federal University for the years 2013, 2014.

\section{References}

Kara -Murza S., Batnikov S., Glazyev S. Where Russia goes. White book of reforms. M.: ALGORYTHM, 2008.

Russian economy effectiveness. DateViews 30.01.2014 www.gks.ru/wps/wcm/connect/rosstat_main/rosstat/ru/statistics/efficiency/\# Esipov V. Shady economic relations and economic criminality in modern Russia reasons. M.: 2007.

Lopatnikov L. P. 2 Ch. 1 About "shock therapy", inflation and prognosis accuracy // Pereval. M.-St.P.: Norma,2006. P. 78-117. ISBN 587857-114-5

Dabrowski M. The World Economy's Impossible Demand // Project Syndicate. 2014. Jan. 29-th.

Tatarkin A.. "Modern economic development imperatives: world trends and russian reality" // International scientific and social magazine "The world of changes", Moscow, RSA Institute, \#1/2014, P. 93-97.

American companies return the production from China back. Date Views 10.01.2014 www.vedomosti.ru/companies/news/16704151/ amerikanskie-kompanii-vozvraschayut-proizvodstvo-iz-kitaya\#ixzz2vjngyC07.

Stiglitz J. Well-done pique: America and new economic order after global crisis. M.: Eksmo, 2011. P. 66

www.km.ru/biznes-i-finansy/2012/01/30/mirovoi-finansovyi-krizis-i-ego-posledstviya/razvitye-strany-nachali-voz

Global Economic Prospects. 2014. Jan. Vol. 8. The World Bank. 2014. P. 16. 
Rodrik D. The Return of Industrial Policy // Project Syndicate. 2010. Apr. 12. URL // http:www.project-syndicate.org/commentary/thereturn-of-industrial-policy

Russia on the way of modern, dynamic and effective economy: Rep. / Under edition. Nekipelova A. M.: RSA, 2013. P. 14.

Biryukov A. "The postindustrial world" or "The postindustrial myph" // Phylosophy and society. 2011. \#2. P. 159.

Vaslavskaya I. State corporate capital in the system of state-private partnership. Report on the First Russian economic congress, Thematic conferences, Political economy of the social state. M.: MSU, Dec. 2009

Moscow Economic Forum. Available at: http://me-forum.ru/ (accessed 02 February 2014).

Tatarkin A.I., Romanova O.A., Lavrikova Y.G. Teoretical Foundations of public-private partnership. Scientific and practical economic and legal Journal of Business, Management and Low number, 2009, no. 1 (19), pp.17-22.

Makarov I. The mechanism of public-private partnership in the transformation of the Russian economy: monograph//M.: Modern economics and Law Publ., 2010, p. 175.

Kireyeva A.V. Public-private partnership as a tool to support innovation: monograph// Moscow: Delo Publ., 2012. P.514.

Grebennikov A.V. Status and prospects of public-private partnership in mechanical engineering: monograph. Kemerevo: Sib. izdat. Group Publ., 2010. P. 203.

Vertakova V. Regional models of interaction between business and universities on the basis of public-private partnership: monograph/l St. Petersburg.: Lehmann Publ., 2013. P.123. 